\title{
Ciliated microeukaryotes (Alveolata: Ciliophora) of a lotic urban system located in Minas Gerais - Brazil
}

\author{
J. A. Vilas Boas ${ }^{a}$, M. V. X. Senra ${ }^{b}$, A. L. Fonseca ${ }^{a}$ and R. J. P Dias ${ }^{b}$ \\ a'Laboratório de Limnologia, Programa de Pós-graduação em Meio Ambiente e Recursos Hídricos, \\ Instituto de Recursos Naturais, Universidade Federal de Itajubá - UNIFEI, Avenida BPS, 1303, \\ Pinheirinho, CEP 37500-903, Itajubá, MG, Brasil \\ 'Laboratório de Protozoologia, Instituto de Ciências Biológicas, Universidade Federal de Juiz de Fora - UFJF, \\ Rua José Lourenço Kelmer, s/n, Martelos, CEP 36036-900, Juiz de Fora, MG, Brasil \\ *e-mail: jessica_biol@outlook.com
}

Received: October 31, 2017 - Accepted: January 2, 2018 - Distributed: August 31, 2019

(With 1 figure)

The phylum Ciliophora is organized in 14 classes with $\sim 8,000$ described species (Gao et al., 2016). Among unicellular microeukaryotes, ciliates are the most specialized, diversified and with the highest complexity in terms of cellular organization (Puytorac, 1994). They typically occupy basal trophic levels and display a wide geographical distribution occurring in almost all environments such as marine, fresh and brackish waters, and also in edaphic systems like soils, mosses and lichens (Lynn, 2008).

Their diversity in lotic systems have been extensively studied in the northern hemisphere because of their potential use as water quality bioindicators (Wiackowski, 1981; Primc, 1988; Groliére et al., 1990; Madoni, 2005). However, scarce information is available in literature about their diversity in aquatic ecosystems in Brazil, even though its privileged hydrological condition. The access to ciliate diversity and biogeography is a challenge tasks because they are diminute organisms, difficult to identify (Finlay and Fenchel, 1999), there is a lack of experienced specialists (Foissner, 2006) and a number of species stay encysted for most of their life cycles (Foissner, 2004). In Brazil, significant works were performed with this emphasis such as conducted in Rio Grande do Sul (Safi et al., 2014), Paraná (Pauleto et al., 2009; Buosi et al., 2011; Velho et al., 2005, 2013), São Paulo (Bagantini et al., 2013; Regali-Seleghim et al., 2011), Pará (Castro et al., 2014), Minas Gerais (Dias et al., 2008, 2010) and Rio de Janeiro (Paiva and Silva-Neto, 2004a, b) states. Inventory studies constitute the first step for development of applied biotechnological usage of ciliates. Regali-Seleghim et al. (2011) highlight the importance of more works surveying the diversity of ciliates in less studied regions of Brazil given their ecological importance. Moreover, establishment of in vitro cultures will contribute with information to biomonitoring programs (Madoni and Romeo, 2006; Shi et al., 2012) and for better evaluation of the biotechnological potential of these organisms (Mansano et al., 2016). This present work aimed to survey the diversity of the species of ciliated protists in a neotropical lotic urban system located in Southern region of Minas Gerais state, Brazil.
The samples were taken from José Pereira stream

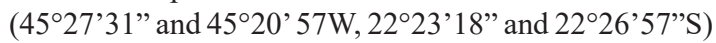
a highly impacted watercourse with in natura disposal of sewage (Thomaz da Silva, 2015) located in the municipality of Itajubá, Minas Gerais, Brazil. A Van Veen dredge was used to collect sediment monthly for over a year (October 2014 to October 2015). The sediment samples were readily transferred to $500 \mathrm{~mL}$ plastic containers and moved to the laboratory to be processed. Each sample were then divided $(\sim 20 \mathrm{~mL})$ into three petri dishes and screened using glass micropipettes. Each Petri dish was analyzed in the day of collecting and weekly for up to 4 weeks. For in vitro cultures, ciliates were transferred to new Petri dishes filled with mineral water where rice grains with shells were added to served as carbon source for bacterial growth that would act to sustain the propagation of the tested ciliates. The ciliates were identified according to Foissner and Berger (1996). The photographic records of in vivo specimens were carried out with the aid of a camera attached to a microscope Olympus BX 51. The main features used in the identification of ciliates were: body shape, position and number of contractile vacuoles, oral and somatic ciliatures, position of macronucleus and shape of inclusions and color and the cytoplasm. Eventually, DAPI, a DNA specific staining method (Kapuscinski, 1995), protargol (Dieckmann, 1995) and dry silver nitrate (Klein, 1958) were used for species confirmation.

We recorded 48 ciliate morphospecies from the sediment samples taken from José Pereira stream (Figure 1). These microorganisms were classified according to Lynn (2008) and distributed into the classes Karyorelictea $(n=1)$, Heterotrichea $(n=6)$, Spirotrichea $(n=15)$, Litostomatea $(n=2)$, Phyllopharyngea $(n=2)$, Colpodea $(n=1)$, Prostomatea $(n=1)$, Oligohymenophorea $(n=20)$ (Table 1$)$. The class Oligohymenophorea were the most abundant in species number being distributed into the sub-classes: Peniculia $(n=6)$, Hymenostomatia $(n=4)$ and Peritrichia $(n=10)$.

Among all these morphospecies, the species Euplotes aediculatus, Euplotes eurystomus, Spirostomum minus and Spirostomum teres, and Paramecium bursaria, Paramecium caudatum and Tetmemena pustulata were 

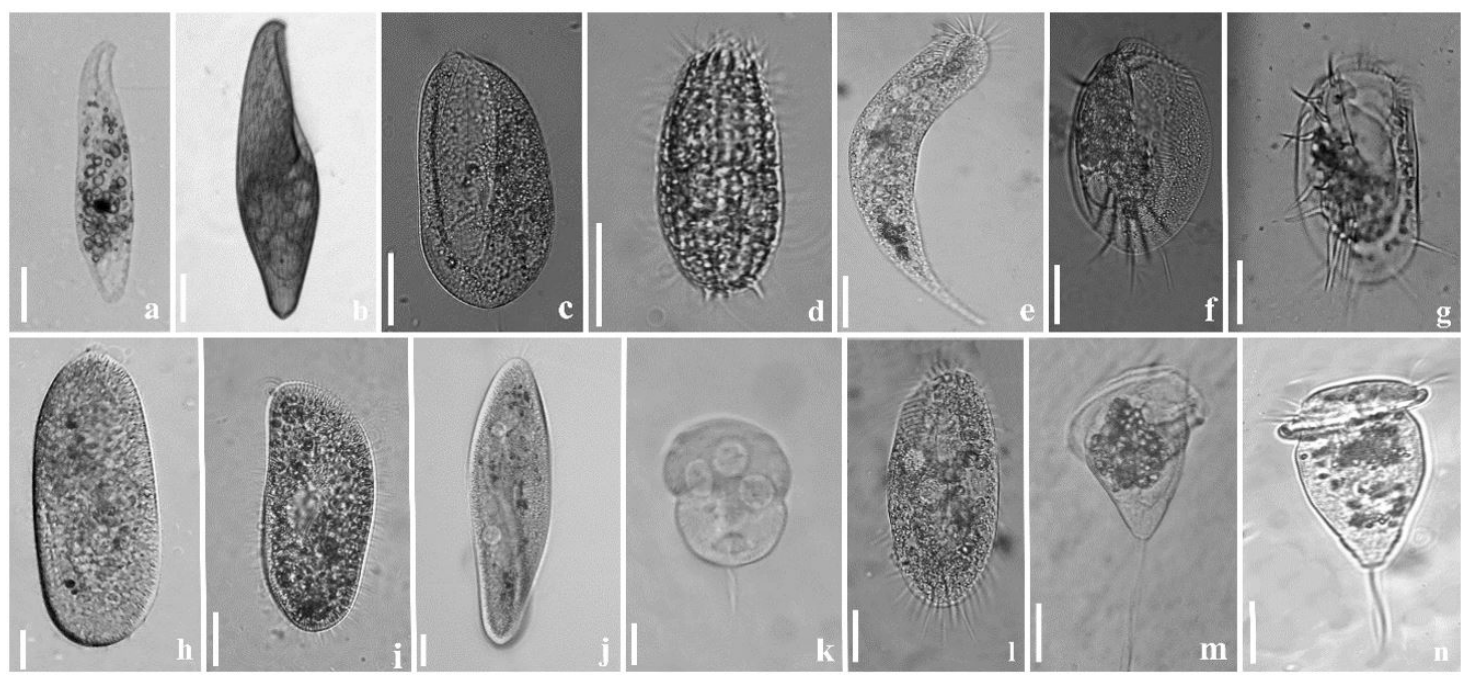

Figure 1. Representatives of ciliated found in José Pereira. (a) Loxodes striatus; (b) Blepharisma sinuosum; (c)Lembadium lucens; (d) Coleps hirtus; (e)Spirotrichea (morphospecies 1); (f) Euplotes aediculatus; (g) Euplotes eurystomus; (h) Frontonia leucas; (i) Paramecium bursaria; (j) Paramecium caudatum; (k) Urocentrum turbo; (1) Tetmemena pustulata; (m) Vorticella campanula; (n) Vorticella convallaria-complex. Barras: $20 \mu \mathrm{m}$.

the ones that best adapted to the in vitro growth conditions (up to several months) using mineral water and rice grains and Cerophyl medium (Sonneborn, 1957), respectively (data not shown).

This study contributed to the understanding of the diversity of ciliated protists in Brazil, since this is the first work in the Southern region of Minas Gerais. Still, such studies can be useful to a better comprehension of the trophic relationships in aquatic environments, can support biomonitoring programs that assess the quality of water as well as the maintenance and conservation of the species with biotechnological potential (Madoni and Romeo, 2006; Regali-Seleghim et al., 2011; Gutièrrez et al., 2011).

In Brazil, the first work on ciliates from freshwater environments were carried out by Cunha in the early twentieth century (Cunha, 1913; Faria and Cunha, 1917; Cunha and Fonseca, 1918) with few recent studies on inventory of these micro-organisms in inland waters (Paiva and Silva-Neto, 2004a, b; Dias, 2007; Dias et al., 2008; Regali-Seleghim et al., 2011; Safi et al., 2014; Sartini, 2012; Mendonça, 2012; Castro et al., 2014; Kuhner et al., 2016). Cotterill et al. (2008) estimated that there are about 40,000 species of free-living ciliates, where only 4,500 species $(\sim 11 \%)$ have been described so far. Recent studies emphasize the need to increase sampling effort in South America for a better understanding of ciliates diversity in this region (Fenchel and Finlay, 2004; Foissner, 2006; Foissner and Hawksworth, 2009), as there are a large number of unexplored environments and potential implication to biomonitoring and conservation of these ecosystems (Mitchell and Meisterfeld, 2005; Cotterill et al., 2008).

The saprobic system for water quality evaluation, and more specifically organic pollution, developed by Kolkwitz and Marsson (1908, 1909), is widely used in biological classification of running water. The original list of indicator species, including ciliates, was revised and expanded (Foissner, 1988). Among the 48 morphospecies found in the stream José Pereira, 23 are included in the saprobic system and are considered biomarkers (Table 1), in which the vast majority were indicative of organically enriched environments (polluted or extremely polluted water), such as Loxodes striatus, Spirostomum teres, Paramecium caudatum, Euplotes aediculatus, Euplotes eurystomus, Tokophrya lemnarum, Cyclidium cf. glaucoma, Carchesium polypinum, Vorticella convallaria-complex, Spirostomum minus, Stentor polymorphus, Stentor roeselii, Aspidisca and Coleps hirtus. This observation is corroborated by a recent study (Thomaz da Silva, 2015) focusing in the quality of the water in this same sampling station, using physical and chemical parameters to classify this lotic system as Class III (highly polluted water) (Brasil, 2005), and highlighted the high levels of electrical conductivity, total coliforms, phosphorus, total nitrogen, ammonia and chlorophyll.

Moreover, we were able to stably maintain the in vitro growth of seven species of ciliates: Euplotes aediculatus, Euplotes eurystomus, Paramecium bursaria, Paramecium caudatum, Spirostomum minus, Spirostomum teres and Tetmemena pustulata. The ability to grow these organisms in vitro using cerophyl medium (Sonneborn, 1957) expands the possibilities of future applied studies such as acute trials (ecotoxicology), detection, characterization and isolation of secondary metabolites, characterization of molecules with antimicrobial activity, contributing to neotropical water monitoring programs (Madoni and Romeo, 2006; Petrelli et al., 2012; Mansano et al., 2016). This present study contributes to a better comprehension about the diversity of ciliated protists in limnic ecosystems in Brazil and emphasizes the importance of development 
Table 1. Ciliated protist species found in José Pereira stream, Itajubá, Minas Gerais, Brazil.

\begin{tabular}{|c|c|c|c|c|c|c|}
\hline Ciliates from Brazilian freshwater ecosystems & $\mathbf{D}$ & $\mathbf{1}^{\text {st }}$ & $2^{\text {nd }}$ & $3^{\text {rd }}$ & $4^{\text {th }}$ & $\mathbf{S}$ \\
\hline Class Karyorelictea & $\mathbf{D}$ & $\mathbf{1}^{\text {st }}$ & $2^{\text {nd }}$ & $3^{\text {rd }}$ & $4^{\text {th }}$ & $\mathbf{S}$ \\
\hline \multicolumn{7}{|l|}{ Order Loxodida } \\
\hline Loxodes striatus & + & - & - & - & - & $\mathrm{p}$ \\
\hline \multicolumn{7}{|l|}{ Class Heterotrichea } \\
\hline \multicolumn{7}{|l|}{ Order Heterotrichida } \\
\hline Blepahrisma sinuosum & + & + & - & - & - & $* *$ \\
\hline Spirostomum minus & + & + & + & + & + & a-b \\
\hline Spirostomum teres & + & + & + & + & + & $\mathbf{p}$ \\
\hline Stentor polymorphus & + & + & - & - & - & $a-b$ \\
\hline Stentor roeselii & + & + & - & - & - & $a-b$ \\
\hline
\end{tabular}

Class Spirotrichea

Sub-class Hypotrichia

Aspidisca cicada

Euplotes aediculatus

Euplotes eurystomus

Sub-class Stichotrichia

Tetmemena pustulata

Stichotrichia (morphospecies 1-9)

Sub-class Oligotrichia

Halteria cf. grandinella

lass Litostomatea

Order Haptorida

Dipleptus sp.

Order Pleutostomatida

Litonotus sp.

Class Phyllopharyngea

1

$1^{\text {st }} \quad 2$

$2^{\text {nd }} \quad 3^{\text {rd }}$

$4^{\text {th }}$

S

Sub-class Suctoria

Order Endogenida

Tokophrya lemnarum

Suctoria (morphospecies 1)

Class Prostomatea

Coleps hirtus

Class Oligohymenophorea

Sub-class Peniculia

Frontonia leucas

Lembadium lucens

Paramecium aurelia-complex

Paramecium bursaria*

Paramecium caudatum

Urocentrum turbo

Sub-class Hymenostomatia

Glaucoma frontata

Hymenostomatia (morphospecies 1-2)

Order Scuticociliatida

Cyclidium cf. glaucoma

Sub-class Peritrichia

Carchesium polypinum

Epistylis sp.

Opercularia sp.

Vorticella convallaria-complex

Vorticella campanula

Vorticella (morphospecies 1-4)

$\mathrm{D}=$ appeared in the same day of assay; $1^{\text {st }}=$ appeared in the first week of assay; $2^{\text {nd }}=$ in the second week; $3^{\text {rd }}=$ in the third week; $4^{\text {th }}=$ in the fourth; $\mathrm{S}=$ saprobicity (Foissner \& Berger, 1996); $\mathrm{p}=$ polysaprobic; $\mathrm{a}=$ alpha-mesosaprobic; $\mathrm{b}=$ beta-mesosaprobic; $* *=$ not classified; $+=$ occurred; $-=$ absent. Dark names represent species that have been successfully in vitro cultivated in mineral water supplemented with crushed rice with shells; *First record in Minas Gerais state. 
of new and efficient growth methods for in vitro culture of these microorganisms aiming future biotechnological end environmental monitoring studies.

\section{Acknowledgements}

This work was partially supported by Coordenação de Aperfeiçoamento de Pessoal de Nível Superior (CAPES) and Fundação de Amparo à Pesquisa do Estado de Minas Gerais (Edital Universal 2016, FAPEMIG). The Conselho Nacional de Desenvolvimento Científico e Tecnológico $(\mathrm{CNPq})$ provided research grant to Roberto Júnio P. Dias (Bolsa de Produtividade PQ) and CAPES to Marcus Vinicius Xavier. We thank Marcelo José de Carvalho for help in laboratory work.

\section{References}

BAGANTINI, I.L., SPÍNOLA, A.L.G., PERES, B.M., MANSANO, A.S., RODRIGUES, M.A.A., BATALHA, M.A.P., LUCCA, J.V., GODINHO, M.J.L., TUNDISI, T.M. and REGALI-SELEGHIM, M.H., 2013. Protozooplankton and its relationship with environmental conditions in 13 water bodies of the Mogi-Guaçu basin - SP, Brazil. Biota Neotropica, vol. 13, pp. 1-12. http://dx.doi.org/10.1590/ S1676-06032013000400016.

BRASIL. Conselho Nacional do Meio Ambiente - CONAMA, 2005. Resolução $n^{\circ} 357$, de 17 de março de 2005. Classificação dos corpos de água. Diário Oficial da República Federativa do Brasil, Brasilia, 18 mar. pp. 27.

BUOSI, P.R.B., PAULETO, G.M., LANSAC-TÔHA, F.A. and VELHO, L.F.M., 2011. Ciliate community associated with aquatic macrophyte roots: effects of nutrient enrichment on the community composition and species richness. European Journal of Protistology, vol. 47, no. 2, pp. 86-102. http://dx.doi.org/10.1016/j. ejop.2011.02.001. PMid:21353502.

CASTRO, L.A., KÜPPERS, G.C., SCHWEIKERT, M., HARADA, M.L. and PAIVA, T.S., 2014. Ciliates from eutrophized water in the northern Brazil and morphology of Cristigera hammeri Wilbert, 1986 (Ciliophora, Scuticociliatia). European Journal of Protistology, vol. 50, no. 2, pp. 122-133. http://dx.doi.org/10.1016/j. ejop.2014.01.005. PMid:24703614.

COTTERILL, F.P.D., AL-RASHEID, K.A.S. and FOISSNER, W., 2008. Conservation of protists: is it needed at all. Biodiversity and Conservation, vol. 17, no. 2, pp. 427-444. http://dx.doi. org/10.1007/s10531-007-9261-8.

CUNHA, A., 1913. Contribuição para o conhecimento da fauna de protozoários do Brasil. Memorias do Instituto Oswaldo Cruz, vol. 5, no. 2, pp. 101-122. http://dx.doi.org/10.1590/S007402761913000200001 .

CUNHA, A.M. and FONSECA, O., 1918. O microplâncton das costas meridionais do Brazil. Memorias do Instituto Oswaldo Cruz, vol. 10, no. 2, pp. 99-103. http://dx.doi.org/10.1590/S007402761918000200002 .

DIAS, R.J.P., 2007. Protistas ciliados (Protista, Ciliophora) encontrados no córrego São Pedro (bacia do rio Paraibuna), município de Juiz de Fora, Minas Gerais: taxonomia, morfologia, biomonitoramento e relações epibióticas. Juiz de Fora: Universidade Federal de Juiz de Fora, 258 p. Dissertação de Mestrado em Ciências Biológicas.

DIAS, R.J.P., CABRAL, A.F., SIQUEIRA-CASTRO, I.C.V., SILVA-NETO, I.D. and D'AGOSTO, M.A., 2010. Morphometric study of a Brazilian strain of Carchesium polypinum (Ciliophora: Peritrichia) attached to Pomacea figulina (Mollusca: Gastropoda), with notes on a high infestation. Zoologia, vol. 27, no. 3, pp. 483-488. http://dx.doi.org/10.1590/S1984-46702010000300024.

DIAS, R.J.P., WIELOCH, A.H.B. and D'AGOSTO, M.A., 2008. The influence of environmental characteristics on the distribution of ciliates (Protozoa, Ciliophora) in an urban stream of southeast. Brazilian Journal of Biology = Revista Brasileira de Biologia, vol. 68 , no. 2 , pp. 287-295. http://dx.doi.org/10.1590/S151969842008000200009. PMid:18660956.

DIECKMANN, J., 1995. An improved protargol impregnation for ciliates yielding reproducible results). European Journal of Protistology, vol. 31, no. 4, pp. 372-382. http://dx.doi.org/10.1016/ S0932-4739(11)80449-9.

FARIA, J.G. and CUNHA, A.M., 1917. Estudos sobre o Microplancton da baía do Rio de Janeiro e suas imediações. Memorias do Instituto Oswaldo Cruz, vol. 1, no. 1, pp. 68-92. http://dx.doi.org/10.1590/ S0074-02761917000100003.

FENCHEL, T. and FINLAY, B.J., 2004. The ubiquity of small species: patterns of local and global diversity. Bioscience, vol. 54, no. 8, pp. 777-784. http://dx.doi.org/10.1641/0006-3568(2004)054[0777:TU OSSP]2.0.CO;2.

FINLAY, B.J. and FENCHEL, T., 1999. Divergent perspectives on protist species richness. Protist, vol. 150, no. 3, pp. 229-233. http://dx.doi.org/10.1016/S1434-4610(99)70025-8. PMid:10575696.

FOISSNER, W. and BERGER, H., 1996. A user-friendly guide to ciliates (Protozoa, Ciliophora) commonly used by hydrobiologists as bioindicators in rivers, lakes, and waste waters, with notes on their ecology. Freshwater Biology, vol. 35, pp. 375-498.

FOISSNER, W. and HAWKSWORTH, D.L., 2009. Protist diversity and geographical distribution. Dordrecht: Springer. http://dx.doi. org/10.1007/978-90-481-2801-3.

FOISSNER, W., 1988. Taxonomic and nomenclatural revision of Sládeček's list of ciliates (Protozoa: Ciliophora) as indicators of water quality. Hydrobiolgia, vol. 166, no. 1, pp. 1-64. http://dx.doi. org/10.1007/BF00017483.

FOISSNER, W., 2004. Some new ciliates (Protozoa, Ciliophora) from an Austrian floodplain soil, including a giant, red "flagship", Cyrtohymena (Cyrtohymenides) aspoecki nov. subgen., nov. spec. Denisia, vol. 13, pp. 369-382.

FOISSNER, W., 2006. Biogeography and dispersal of microorganisms: a review emphasizing protists. Acta Protozoologica, vol. 45, pp. 111-136.

GAO, F., WARREN, A., ZHANG, Q., GONG, J., MIAO, M., SUN, P., XU, D., HUANG, J., YI, Z. and SONG, W., 2016. The all-data-based evolutionary hypothesis of ciliated protists with a revised classification of the Phylum Ciliophora (Eukaryota, Alveolata). Nature/Scientific Reports, vol. 29, pp. 1-14. PMid:27126745.

GROLIÈRE, C.A., CHAKLI, R., SPARAGANO, O. and PEPIN, D., 1990. Application de la colonisation d'un substrat artificiel par les ciliés à l'étude de la qualité des eaux d'une riviére. European Journal of Protistology, vol. 25, no. 4, pp. 381-390. http://dx.doi. org/10.1016/S0932-4739(11)80131-8. PMid:23196052.

GUTIÉRREZ, J.C., AMARO, F., DIAZ, S., DE FRANCISCO, P., CUBAS, L.L. and MARTIN-GONZALEZ, A., 2011. Ciliate metallothioneins: unique microbial eukaryotic heavy-metal-binder molecules. Journal of Biological Inorganic Chemistry, vol. 16, no. 7, pp. 1025-1034. http://dx.doi.org/10.1007/s00775-011-0820-9. PMid:21785894. 
KAPUSCINSKI, J., 1995. DAPI: a DNA-specific fluorescent probe. Biotechnic \& Histochemistry, vol. 70, no. 5, pp. 220-233. http://dx.doi.org/10.3109/10520299509108199. PMid:8580206.

KLEIN, B.N., 1958. The "dry" silver method and its proper and use. The Journal of Protozoology, vol. 5, no. 2, pp. 99-103. http:// dx.doi.org/10.1111/j.1550-7408.1958.tb02535.x.

KOLKWITZ, R. and MARSSON, K., 1908. Ökologie der pfanzlichen Saprobien. Berichte der Deutschen Botanischen Gesellschaft, vol. 26, pp. 505-519.

KOLKWITZ, R. and MARSSON, K., 1909. Ökologie der tierischen Saprobien. Internationale Revue der Gesamten Hydrobiologie und Hydrographie, vol. 2, no. 1-2, pp. 126-152. http://dx.doi. org/10.1002/iroh.19090020108.

KÜHNER, S., SIMÃO, T.L.L., SAFI, L.S.L., GAZULHA, F.B., EIZIRIK, E. and UTZ, L.R.P., 2016. Epistylis portoalegrensis n. sp. (Ciliophora, Peritrichia): a new freshwater Ciliate species from Southern Brazil. The Journal of Eukaryotic Microbiology, vol. 63, no. 1, pp. 93-99. http://dx.doi.org/10.1111/jeu.12252. PMid:26198754.

LYNN, D.H., 2008. The ciliated protozoa: characterization, classification and guide to the literature. 3rd ed. New York: Springer Press.

MADONI, P. and ROMEO, M.G., 2006. Acute toxicity of heavy metals towards freshwater ciliated protists. Environmental Pollution, vol. 141, no. 1, pp. 1-7. http://dx.doi.org/10.1016/j. envpol.2005.08.025. PMid:16198032.

MADONI, P., 2005. Ciliated protozoans communities and saprobic evaluation of water quality in the hilly zone of some tributaries of the Po River (northern Italy). Hydrobiologia, vol. 541, no. 1, pp. 55-69. http://dx.doi.org/10.1007/s10750-004-4667-8.

MANSANO,A.S., MOREIRA, R.A., PIEROZZI, M., OLIVEIRA, T.M.A., VIEIRA, E.M., ROCHA, O. and REGALI-SELEGHIM, M.H., 2016. Effects of diuron and carbofuran pesticides in their pure and commercial forms on Paramecium caudatum: The use of protozoan in ecotoxicology. Environmental Pollution, vol. 213, pp. 160-172. http://dx.doi.org/10.1016/j.envpol.2015.11.054. PMid:26890484.

MENDONÇA, H.S.S., 2012. Ciliados planctônicos e epibentônicos do rio das Velhas e Tributários, MG: ecologia e uso potencial para bioindicação da qualidade das águas. Ouro Preto: Universidade Federal de Ouro Preto, 319 p. Dissertação de Mestrado em Ciências Biológicas.

MITCHELL, E.A.D. and MEISTERFELD, R., 2005. Taxonomic confusion blurs the debate on cosmopolitanism versus local endemism of free living protists. Protist, vol. 156, no. 3, pp. 263-267. http:// dx.doi.org/10.1016/j.protis.2005.07.001. PMid:16325540.

PAIVA, T.S. and SILVA-NETO, I.D., 2004a. Ciliate protists from Cabiúnas lagoon (Restinga de Jurubatiba, Macaé, Rio de Janeiro) with emphasis on water quality indicator species and description of Oxytricha marcili sp. n. Brazilian Journal of Biology $=$ Revista Brasileira de Biologia, vol. 64, no. 3A, pp. 465-478. http://dx.doi. org/10.1590/S1519-69842004000300010. PMid:15622844.

PAIVA, T.S. and SILVA-NETO, I.D., 2004b. Comparative morphometric study of three species of Apoamphisiella Foissner, 1997 (Ciliophora: Hypotrichea) from Brazilian locations, including a description of Apoamphiseilla foissneri sp. n. Zootaxa, vol. 505, no. 1, pp. 1-26. http://dx.doi.org/10.11646/zootaxa.505.1.1.

PAULETO, G.M., VELHO, L.F.M., BUOSI, P.R.B., BRÃO, A.F., LANSAC-TÔHA, F.A. and BONECKER, C.C., 2009. Spatial and temporal patterns of ciliate species composition (Protozoa: Ciliophora) in the plankton of the Upper Paraná River floodplain.
Brazilian Journal of Biology $=$ Revista Brasileira de Biologia, vol . 69, no. 2, suppl., pp. 517-527. http://dx.doi.org/10.1590/S151969842009000300007. PMid:19738959.

PETRELLI, D., BUONANNO, F., VITALI, L. and ORTENZI, C., 2012. Antimicrobial activity of the protozoan toxin climacostol and its derivatives. Biologia, vol. 67, no. 3, pp. 525-529. http:// dx.doi.org/10.2478/s11756-012-0030-0.

PRIMC, B., 1988. Trophic relationships of ciliated Protozoa developed under different saprobic conditions in the periphyton of the Sava River. Periodicum Biologorum, vol. 90, pp. 349-353.

PUYTORAC, P., 1994. Phylum Ciliophora Doflein, 1901. In: P. PUYTORAC, ed. Traité de zoologie, infusoires ciliés: systématoque. Paris: Masson, vol. 2, no. 2, pp. 1-15.

REGALI-SELEGHIM, M.H., GODINHO, M.J.L. and MATSUMURA-TUNDISI, T., 2011. Checklist dos "protozoários" de água doce do Estado de São Paulo, Brasil. Biota Neotropica, vol. 11, suppl. 1, pp. 135-172. http://dx.doi.org/10.1590/S167606032011000500014 .

SAFI, L.S.L., FONTOURA, N.F., SEVERO, H.J. and UTZ, L.R.P., 2014. Temporal structure of the peritrich ciliate assemblage in a large Neotropical lake. Zoological Studies, vol. 53, pp. 1-12. http://dx.doi.org/10.1186/s40555-014-0017-3.

SARTINI, B.E.S., 2012. Composição e estrutura da taxocenose de ciliados peritríqueos (Ciliophora, Peritrichia) em ambientes lóticos com gradiente de poluição orgânica e aspectos ecológicos da relação epibiótica de peritríqueos e moluscos gastrópodes. Juiz de Fora: Universidade Federal de Juiz de Fora, 95 p. Dissertação de Mestrado em Ciências Biológicas.

SHI, X., LIU, X., LIU, G., SUN, Z. and XU, H., 2012. An approach to analyzing spatial patterns of protozoan communities for assessing water quality in the Hangzhou section of Jing-Hang Grand Canal in China. Environmental Science and Pollution Research International, vol. 19, no. 3, pp. 739-747. http://dx.doi. org/10.1007/s11356-011-0615-0. PMid:21927840.

SONNEBORN, T.M., 1957. Breeding systems, reproductive methods and species problems in Protozoa. In: E. MAYR, ed. The species problem. Amer: Association for the Advancement of Science, pp. 155-324.

THOMAZ DA SILVA, S.C.M., 2015. Caracterização dos efeitos genotóxicos induzidos por amostras de água provenientes do ribeirão José Pereira, sul de Minas Gerais: subsídio para monitoramento da qualidade da água. Itajubá: Universidade Federal de Itajubá, 69 p. Dissertação de Mestrado em Meio Ambiente e Recursos Hídricos.

VELHO, L.F.M., LANSAC-TÔHA, S.M., BUOSI, P.R.B., MEIRA, B.R., CABRAL, A.F. and LANSAC-TÔHA, F.A., 2013. Structure of planktonic ciliates community (Protist, Ciliophora) from an urban lake of southern Brazil. Acta Scientiarum. Biological Sciences, vol. 35, no. 4, pp. 531-539. http://dx.doi.org/10.4025/ actascibiolsci.v35i4.18579.

VELHO, L.F.M., PEREIRA, D.G., PAGIORO, T.A., SANTOS, V.D., PERENHA, M.C.Z. and LANSAC-TÖHA, F.A., 2005. Abundance, biomass and size structure of planktonic ciliates in reservoirs with distinct trophic states. Acta Limnologica Brasiliensia, vol. 17, pp. 361-371.

WIACKOWSKI, K., 1981. Analysis of Ciliata from polluted sector of the River Drwinka on the basis of binary data. Acta Hydrobiologica, vol. 23, pp. 319-329. 